\title{
O legado musical de Arnold Schoenberg e seus reflexos na América Latina: 1951-2021
}

\author{
Amilcar Zani \\ Universidade de São Paulo \\ amilcarzani@gmail.com \\ Heloisa Zani \\ Universidade de São Paulo \\ heloisazani@gmail.com \\ Eliana Monteiro da Silva \\ Universidade de São Paulo \\ ms.eliana@usp.br
}

\section{Apresentação do Dossiê}

Este dossiê homenageia Arnold Schoenberg (1874-1951) aos 70 anos de seu falecimento. Idealizador da técnica que revolucionou a composição erudita ocidental - o dodecafonismo, ou, a técnica de escrever com os doze sons da escala cromática aplicando um raciocínio serial este pintor, compositor, professor, músico teórico e inventor marcou mundialmente compositores e compositoras com sua inserção no atonalismo (ou, como preferia designar, na pantonalidade), além do expressionismo musical e pictórico.

Schoenberg trabalhou de forma inovadora elementos musicais como forma, harmonia, ritmo, timbre e melodia. Sua obra musical engloba composições de estilos diversificados, passando também por períodos que vão da experimentação à estruturação de soluções para o que entendia serem os principais problemas da música do século XX. Admirador e apologista do contraponto e da variação progressiva de motivos, principalmente melódicos e rítmicos, desenvolveu um raciocínio que utilizava a série dos doze sons como J. S. Bach havia feito com as escalas diatônicas, ao sistematizar ideias advindas da Idade Média e do Renascimento, projetando-as rumo ao futuro.

Nada mais natural, portanto, que reflexos de suas ideias teóricas, musicais e didáticas tenham chegado a outros continentes através de livros, testemunhos de colegas e aluno(as), partituras e gravações, entre outros, como abordam os diversos artigos deste dossiê. Entre os diferentes enfoques propostos estão os que se seguem:

Eduardo Seincman, em seu artigo "Meus 'encontros' com Arnold Schoenberg: ideia ou representação?", fala justamente destas experiências vivenciadas na qualidade de aluno de 
música, compositor e professor/pesquisador. O autor, que traduziu três importantes obras didáticas de Schoenberg, reflete sobre as "novas formas de abordar, técnica e conceptualmente, o estudo das formas, contraponto e harmonia musicais" empregadas pelo compositor.

Em “A Forma da Noite: uma proposta de análise formal da Noite Transfigurada", André de Cillo Rodrigues realiza "um exame crítico de algumas propostas de segmentação formal [da Noite Transfigurada, de Schoenberg] a partir dos trabalhos de autores como Swift (1977), Pfannkuch (1963), Frisch (1993) e Wellesz (1968)”. O artigo busca também refletir sobre "o anseio de incorporar a tradição e a necessidade de invenção" presentes nessa e em outras obras do compositor.

Também no sentido de compreender o movimento e as mudanças de paradigmas propostas pela chamada Segunda Escola de Viena, Amilcar e Heloísa Zani trazem em O Quarto Elemento... um panorama da vida de Edward Steuermann, pianista e compositor que apresentou em primeiras audições a obra para piano de Schoenberg, Webern e Berg. Pianistas e pesquisadores da "Coleção Clara e Edward Steuermann, na Divisão de Musica da Biblioteca do Congresso de Washington, nos Estados Unidos", os autores discutem a importância da obra de Steuermann para a divulgação e consequente amadurecimento da escrita dodecafônica de Schoenberg e de seus discípulos.

Seguindo no tema da interpretação musical, o artigo Reprodução musical: um diálogo sobre interpretação musical em Schönberg, Kolisch e Adorno, de Vinícius Benalia Penteado e Mário Videira, levanta questões sobre a relação entre partitura, obra musical e performance na visão destes três autores. São debatidos conceitos como subjetividade e objetividade, limites da autonomia do(a) intérprete e reprodução musical verdadeira.

A influência de Schoenberg na música da América Latina é abordada em três artigos:

Em O que um Lied de Schoenberg pode nos ensinar sobre uma Sonata de Santoro?, Rodolfo Coelho de Souza faz um recorrido sobre a evolução do dodecafonismo como "método de composição", resultante de caminhos diversos trilhados por compositores na Europa e nos Estados Unidos. Em vista disso, o autor questiona um argumento frequente entre pesquisadores de que faltaria ortodoxia na aplicação da técnica pelo brasileiro Claudio Santoro, fazendo uma análise comparativa entre sua Sonata 1942 e o Lied Sommermüg Op. 48 No 1 de Arnold Schoenberg. 
Por sua vez, Marisa Milan Candido e Eliana Monteiro da Silva tratam da questão da expressividade na obra de Schoenberg no artigo Eunice Katunda e seu Quinteto Schoenberg: uma homenagem ao criador do dodecafonismo. Mostrando como a compositora brasileira utilizou em seu quinteto, ao mesmo tempo, "melodias de inspiração folclórica nacional" e hexacordes usados por Schoenberg na obra Ode to Napoleon Buonaparte Op. 41, as autoras refletem sobre as supostas intenções do próprio Schoenberg de humanizar o dodecafonismo, como propõe o analista Walter Bailey (apud SHAW; AUNER, 2010).

O terceiro artigo que relaciona a produção musical latino-americana `a obra de Schoenberg é Arnold Schoenberg e Yves Rudner Schmidt: uma relação musical, de Daniel Cristiano Santos. A partir da "Teoria dos Conjuntos (Forte, 1971)", o autor verifica "proximidade na utilização de conjuntos sonoros" por parte dos compositores citados nas obras Angústia, de Schmidt, e Seis Pequenas Peças para Piano Op.19 n. 6, de Arnold Schoenberg.

Contribuíram em inglês os autores Achille Picchi e Tristan Guillermo Torriani. Em Nacht, from Arnold Schoenberg's Pierrot Lunaire: a perspective from the Art Song Theory on the text-music relationships and its unfoldings, Picchi examina em que medida as "relações texto-música" e as "relações numéricas" empregadas por Schoenberg no oitavo melodrama de seu ciclo Pierrot Lunaire influenciam a "percepção e performance da obra".

Já Torriani traz uma abordagem filosófica sobre Schoenberg e sua obra no contexto do Modernismo pós-guerra. Em Arnold Schoenberg amidst the struggle between scientific materialism and spiritual revival, o autor aborda a postura do compositor em meio aos conflitos entre "materialismo científico e os movimentos de renovação espiritual", sua relação com pensadores como Adorno e Thomas Mann e sua dimensão religiosa e espiritual, apontada por Torriani como insuficientemente reconhecida.

Encerra este dossiê a partitura comentada de Avant-Retard, para Flauta em Do e Flauta em Sol, da compositora brasileira Silvia de Lucca. Envolta no ambiente das múltiplas possibilidades de aplicação do pensamento serial que norteou o dodecafonismo de Schoenberg, a compositora deixa-se "seduzir pelo que consider[a] uma atmosfera francesa nesta peça, acima de tudo etérea e sensorial, de leveza e luminosidade, apesar do esquema formal determinando com rigor diferentes elementos estruturais". Composta em 1991, quando Silvia de Lucca residia em Genebra, a peça Avant-Retard denota influência de compositores como Olivier Messiaen e Arthur Honegger, bem como da Segunda Escola de Viena. 
